\title{
BİR DİL SÜRÇMESİ TÜRÜ OLARAK ÇAPRAZLAMA VE TÜRKÇE ÖRNEKLER BAĞLAMINDA YAPISAL ÖZELLİKLERİ
}

\author{
SPOONERISM AS A SLIP OF THE TONGUE AND ITS \\ STRUCTURAL CHARACTERISTICS IN THE CONTEXT OF \\ TURKISH EXAMPLES
}

Issa SARI*

\begin{abstract}
$\ddot{O} z$
Dil sürçmeleri, daha çok konuşmadaki geçici hatalar olarak algılansa da, çeşitli kalıplar ve örneklemeler etrafinda şekillenmeleri, farklı nedenlere bağlı olarak ortaya çıkabilmeleri, dil mekanizmasının işleyişi hakkında fikir verebilmeleri gibi özellikleri dolayısıyla bilimsel olarak incelenmesi ve sinuflandırlmasi gereken konular arasındadır. Ancak konuyla ilgili yapılacak araştırma ve incelemelerin tıp ve psikoloji başta olmak üzere farklı disiplinlerle bir arada çalışmayı gerektirmesi, ayrıca sürçmelerin daha çok konuşmaya dayalı olması, dolayısıyla çoğu zaman kayıt altına alınmış somut veriler şeklinde sunulamaması, konu üzerine çalışmayı zorlaştırmaktadır. Bu bakımdan dil sürçmeleri, gerek Türkolojide gerek Türk dilbiliminde de bir çalışma alanı olarak gelişme gösterememiştir.

Dil sürçmelerinin ilgili çalışmalarda genelleştirilerek belli kategoriler altında ele alınan çeşitli türleri vardır. Bunların bir kısmını da, Batı literatüründe spoonerism olarak adlandırılan ve doğal konuşmada, bir cümle içerisindeki unsurları ses veya sözcük düzeyinde belli oranda yerlerinin değiştirilmesiyle ortaya çıkan dil sürçmesi oluşturur. Bu çalışmada, Türkçede çaprazlama, makaslama, mübadele, karmacılık gibi farklı terimler etrafinda tanımlanan ve bir dil oyunu olarak da işlev kazanabilen ilgili sürçme, gerek kişisel gözlemlere dayanılarak gerek yazll basında ve internette yer alan, hatta tartışılı örnek gösterilen veriler göz önünde bulundurularak kapsayıcı bir şekilde incelenecek ve yaygın örnekleriyle açıklanmaya çalışılacaktır.
\end{abstract}

Anahtar Kelimeler

Dil sürçmesi, çaprazlama, konuşma hataları, dil yetisi.

\begin{abstract}
Although considered temporary errors in speech, slips of the tongue should be investigated and evaluated scientifically since they shape among various patterns and samplings, occur depending on different factors, and may give ideas on the process of the language mechanism. However, it is difficult to work on the topic since it requires a collaboration and joint work among different disciplines such as physic and psychology. Besides, slips of the tongue depend and best observed on natural speech and by this reason, attesting significant examples is troublesome and most of the time
\end{abstract}

Yrd. Doç. Dr., Hitit Üniversitesi Fen-Edebiyat Fakültesi Türk Dili ve Edebiyatı Bölümü, isasari@hitit.edu.tr 
it is not possible to record relevant slips of the tongue. In this respect, studies on slips of the tongue could not make progress in both Turcology and Turkish linguistics.

Slips of the tongue have several types, which are generalized and categorized on related studies. Spoonerism, which occurs in natural speech and shows phonological and morphological/lexical features in syntactic formations is one of the slips of the tongue. In this work, this kind of slip of the tongue will be tried to be explained along with some widespread examples from Turkish discourses, which is named çaprazlama, makaslama, mübadele, karmacllı hitherto in the Turkish language. Some personal observations will also be touched upon and dealt with respect to the data found on the Internet and social media.

\section{Keywords}

Slip of the tongue, spoonerism, crosswise, speech errors, language competence. 


\section{GíRIŞ}

Genel olarak, "bir konuşmanın herhangi bir kasıt olmadan, dinleyici açısından kolayca fark edilebilecek derecede amaçlanan formundan sapması" şeklinde tanımlanabilecek dil sürçmeleri, Türkolojide ve Türk dilbiliminde yeterince çalışılmamış konular arasındadır. Konunun dilbilimsel olarak Batıda derinlemesine araştırılması da 1970'li yıllarda başlar (Carroll 2008: 194, ayrıca bk. Fromkin 1973, Fromkin 1980, Cutler 1982). Öncesinde, sadece dilbilgisel açıdan doğru yapıları incelemek adeta bir gelenek hâlini almış; dilbilgisel olmayan ifadeler, konuşmadaki hatalar ve sürçmeler görmezden gelinmiştir (Fromkin 1980: 11; Baars 1992: vii). Bunda, konuşma esnasında gerçekleşen hataların, dilbilgisel yapıyla ilgili uyumsuzlukların ve sürçmelerin sadece dille değil tıpla, daha özel olarak da psikoloji ve nörolojiyle yakından ilgili olmasının, dolayısıyla bu tür vakaların disiplinler arası bir bakış açısı ve yaklaşım gerektirmesinin getirdiği zorluğun da etkili olduğu söylenebilir. Öyle ki Freud, dil sürçmelerindeki bilinçaltı duruma işaret etmiş; sürçmelerin, bilinçaltının bir yansıması olduğunu, bastırılmış duygu ve düşüncelerin uygun zeminde dil sürçmesi olarak yansıyabileceğini belirtmiş ve bu durumu psikanalizle açıklamaya çalışmıştır (1995). Ancak konuyla ilgili yapılan son araştırmalar, tüm dil sürçmelerinin bilinçaltıyla ilişkilendirilmesinin güç olacağını ve sürçmelerin sadece küçük bir kısmının bilinçaltını ilgilendirdiğini göstermektedir (Goldstein 2008: 381). Bu hususta, bilinçaltıyla ilişkili olma dışında yorgunluk, sinirlilik, korku, telaş, panik, yoğun duygu hâli, açlık veya çeşitli patolojik durumlar gibi pek çok dil dışı etken, dil sürçmelerinin temel sebepleri arasında değerlendirilebilir. Sürçmelerin nedenleri, daha çok dil dışında gerçekleştiği için, bu vakaların araştırılması da doğal olarak dilbilimden başka disiplinlerin çalışma alanına girecektir.

Sürçmelerin doğal/anlık konuşma esnasında ortaya çıkmaları, çoğu durumda yazıya yansımamaları ve referans olarak gösterilebilecek nitelikte bir veri olarak kayıt altına alınamamaları; tespit edilmelerini, ayrıca konuyla ilgili yargılara varmayı ve çalışmayı zorlaştırmaktadır. Diğer bir ifadeyle sürçmelerin rastlantısal oluşu, ilgili örneklerin sayıca az olmasına sebep olur (Sofu 2001: 198). Ancak, gelişen teknolojik imkânlarla beraber doğal konuşmanın, dolayısıyla dil sürçmelerinin de çeşitli cihazlarla kayıt altına alınması mümkün hâle gelmiş ve böylece konu üzerinde değerlendirme yapmaya imkân tanıyacak somut veriler ortaya çıkmaya başlamıştır. Öyle ki, artık dil konuşurları, yaptıkları sürçmeleri ağ sayfaları üzerinden de paylaşmakta veya bu konuda yorumlar yapmaktadır. ${ }^{1}$

\section{DİL SÜRÇMELERINIIN GENEL ÖZELLİKLERİ}

Dil sürçmelerinin ses, biçimbirim, öbek, cümle gibi düzeylerde veya bu düzeylerin birden fazlasını ilgilendirecek nispette çeşitli türleri vardır: farklı bir sesi telaffuz etmek, seslerin sırasını değiştirmek, yanlış biçimbirimleri işletmek, öbek sırasını değiştirmek, ilgisiz veya yanlış sözcük kullanmak, aynı sesleri, biçimbirimleri veya sözcükleri tekrarlamak, sesleri benzeştirmek, gerekli bir birimi yapıdan çıkarmak, birimleri birbirine harmanlamak, sözcüklerin sırasını karıştırmak gibi.

Dil sürçmeleri, insan zihninin ve dil yetisinin kapasitesine dair ipuçları verir. Öyle ki, konuşmadaki mantıksal hatalar, dilbilgisel yapıyla uyumsuzluklar, ayrıca yeni

Bu hususta, Google gibi yaygın arama motorlarında, sosyal ağlarda veya Ekşi Sözlük gibi platformlarda ilgili anahtar kelimeler girilerek yapılan aramalar yüz binlerce sonuç vermektedir. 
sözcükler/ifadeler insan zihni tarafından anında sezilir ve ortada bir "yanlış" veya yenilik olduğunun farkına varılır. Bu da, hızlı bir tanımlama ve çözümlemeyle mümkündür. Diğer bir ifadeyle, insanın sahip olduğu algılama kabiliyeti, yani idrak, duyduğu veya gördüğü dilsel yapıları çözümleyip bunları daha öncekilerle karşılaştırarak tanımlamasına imkân verir. Bu karşılaştırma ve tanımlama esnasında, varsa hatalar/yeni olgular fark edilir ve adeta farklı bir mekanizma devreye girerek ortada sorunlu/değişik bir durumun olduğu hissedilir. Diğer taraftan dil sürçmeleri, bir hata olarak kabul edilseler de, farklı dilsel yapıların oluşmasına zemin hazırlayabilir. Bu hususta Dell, dil sürçmelerinin dilin türetkenliğinin bir göstergesi olduğunu vurgular ve örneğin biçimbilgisel hataların, anlık sözcükler türettiğini ifade eder (1986: 286). Bu anlık sözcükler ise zaman içerisinde toplum geneline yayılarak yeni bir sözcük olarak kabul görebilir. Dolayısıyla dil sürçmeleri yeni sözcüklerin oluşumunda rol oynayabilir ve bir dilin sözvarlığına, dil sürçmesiyle ortaya çıkmış sözcükler dâhil edilebilir. Öte yandan dil sürçmeleri, sözcüklerin veya seslerin insan zihninde nasıl muhafaza edildiğiyle veya derin yapıdan yüzey yapıya aktarımların nasıl gerçekleştiğiyle ilgili ipuçları verebilir.²

Doğal konuşmada, konuşucu, yaptığı dil sürçmesinin farkına varmayabilir veya varsa dahi (a) dinleyicinin ne kastedildiğini anlayacağını düşünerek, (b) dinleyicinin sürçmeyi fark etmediğini varsayarak veya (c) konuşmanın akışını bozmamak için düzeltme ihtiyacı hissetmeyebilir. Ancak dinleyici, dil sürçmesinin farkına varması durumunda, samimiyet derecesine göre konuşucuya gülebilir, onunla alay edebilir veya rencide etmekten kaçınmak için herhangi bir tepki vermeyebilir. Ayrıca siyasetçi, sanatçı gibi tanınmış kişilerin yaptıkları dil sürçmeleri, toplum genelince eğlence amaçlı kullanılabilir. Bu hususta, özellikle siyasîlerin yaptıkları dil sürçmeleri ve gaflar, bilhassa sosyal medyada ve çeşitli video paylaşım sitelerinde sıkça izlenmekte, yorumlanmakta ve paylaşılmaktadır. Bu yönüyle dil sürçmelerinin toplumsal bir boyut taşıdığı ve toplumdilbilimsel açıdan da incelenmesi gerektiği savunulabilir.

Tamamlanmış bir doğal konuşma geri alınamaz, düzenlenemez veya silinemez. Diğer bir ifadeyle, konuşma gerçekleştikten sonra geriye dönüş mümkün değildir. İşlemler sadece daha sonra yapılacak eklemeler ve düzeltmelerle sınırlıdır. Buna karşın yazıda, bu tür işlemler kolaylıkla yapılabilir. Hatalı yazılan bir ifade düzeltilebilir veya yeniden düzenlenebilir, silinebilir. Bu noktada, yazıya yansıyan dil sürçmelerinin ya büyük bir dikkatsizlik sonucu ya da kasıtlı olarak yapıldığını savunmak mümkündür. Dolayısıyla yazımdaki sürçmeler çoğu durumda bir yazım yanlışı, retorik araç veya oyun olarak değerlendirilebilir. Bu hususta Cöntürk (2006), dil sürçmelerinin edebiyatta, daha özel olarak da şiirlerdeki durumuna temas etmiştir. İlgili kullanımlar bilinçli olarak gerçekleştirilmektedir ve bir dil sürçmesinin oyun veya retorik amaçlı kullanımlarına örnek teşkil etmektedir.

\section{BİR DİL SÜRÇMESİ TÜRÜ OLARAK ÇAPRAZLAMA}

İngilizcede spoonerism ${ }^{3}$ terimi etrafında ele alınan, Türkçede ise çaprazlama, makaslama, mübadele veya değiştiri terimleriyle açıklanan dil sürçmesi türü, ortaya çıkışı itibariyle ötekilerden farklılaşır. Bu dil sürçmesi de diğerleri gibi, genellikle psikodilbilim veya konuşma bozuklukları gibi çalışma alanları kapsamında değerlendirilir ve genel itibariyle iki sözcügün ilk seslerinin yerlerinin değiştirilmesine dayalı bir konuşma hatası olarak tanımlanır (Warren 2013: 250). Esasında çaprazlama, sadece seslerle sınırlı değildir. Daha genel olarak, bir cümle

Konuyla ilgili olarak Fromkin (1973) ve Baars (1992) gibi kaynaklara bakılabilir.

Bu kavram, 1844-1930 yılları arasında Oxford'da yaşamış New College yöneticisi William Archibald Spooner'ın yaptı̆̆ı ilgili dil sürçmelerinin incelenmesiyle birlikte literatüre yerleşmiştir (Hofstadter 1995: 243; Horberry 2010: 104). 
veya öbek içerisindeki unsurların işlev olarak ayn pozisyondakilerle yerleri bire bir olarak değişebilir. Bu da sesten daha büyük unsurların çaprazlamasını ortaya çıkarır. Bu yönüyle çaprazlama, her ne kadar yeterli olmasa ve tüm yönlerine temas edilmemişse de, Milli Eğitim Bakanlığ tarafından yayımlanan Türk Ansiklopedisinin 11. cildinde ilgili madde başı altında şu şekilde tanımlanmış ve örneklendirilmiştir:

"Yan yana söylenen iki kelimenin başındaki seslerin, hecelerin ya da kelimelerin birbiriyle yer değiştirmesi şeklindeki dil sürçmesi ya da oyununa verilen ad. Taş basması yerine Baş

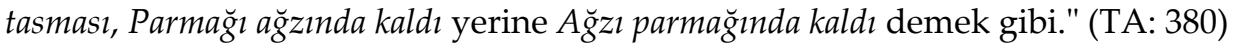

Dilbilim Terimleri Sözlüğü'nde (DTS) ise aynı ifadelere ek olarak, "bir kelimedeki hecelerin birbiriyle yer değiştirmesi" özelliğine yer verilmiştir. Ancak bu durum, daha çok göçüşmeyi (metatez) ilgilendirir. Diğer bir ifadeyle, bir sözcük içerisindeki hecelerin veya seslerin yer değiştirmesi, göçüşme durumunu yansıtır. Çaprazlamada ise farklı sözcükler arasında unsur değişimi, diğer bir ifadeyle sözcükten daha büyük yapılanmalar arasındaki değişim söz konusudur.

Usta, bu dil sürçmesi türünü mübadele terimiyle karşılar (2005: 88-89). Cöntürk ise değiştiri başlığı altında, ilgili sürçmenin sinir sistemindeki bir zayıflık (veya özellik) dolayısıyla ses ve heceler arasındaki tabii bağlantıların izlenememesi sonucu ortaya çıktığına değinip Türk şiirindeki örneklerini verir (2006: 445-451). Şiirdeki kullanımlar ise kasitlı olarak ortaya çıkarılmıştır. Dolayısıyla, yukarıda da belirtildiği üzere, oyun veya muziplik maksadıyla, ayrıca stilistik amaçlarla bilinçli olarak çaprazlamaya başvurulabilir.

Dil Bilimi Terimleri Sözlü̈̆̈̈'nde kavramı tanımlayan Karaağaç (2013: 525), karmacıllk başlığı altında "Farklı hece veya sözlerin etkilenen bölümlerinde sıranın değişmesi olup, uzak yer değiştirme (distant metathesis) olarak da bilinir." şeklinde açıklama yapar. Ancak, yukarı da belirtildiği üzere, yer değiştirme (metathesis) ve çaprazlama (burada karmacılık=spoonerism) farklı dilsel olgulardır (bk. Şekil 1).
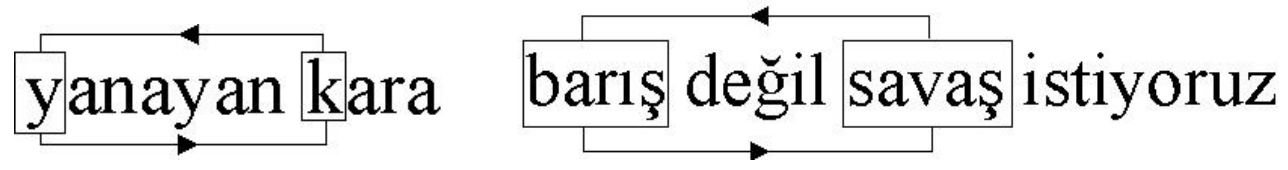

Şekil 1: Ses ve sözcük düzeyinde çaprazlama şemaları

Bir çaprazlama esnasında beyinde neler olduğunu gözlemlemek için Spoonerisms of Laboratory-Induced Predisposition (SLIP) adlı bir teknik geliştirilmiştir. Bu teknik kullanılarak denekler üzerinde yapılan testler sonucunda, çaprazlamalarda beynin sol tamamlayıcı motor alanının (SMA) yakınında veya içerisinde etkileşimler olduğu önerilmiştir. Ayrıca, bir çaprazlama öncesinde, beyinde aynı anda harekete geçen ve birbiriyle rekabet hâlinde olan konuşmaya dayalı iki plandan yanlış olanının galip geldiği varsayılmıştır (Kemmerer 2015: 174176). Tüm bunlar, çaprazlama dâhil çoğu dilsel olgunun ortaya çıkış süreçlerinin deneysel ve bilişsel olarak da incelenmesi gerektiğine işaret etmektedir.

Çaprazlamaların farklı dil konuşurları, yani çaprazlamanın ortaya çıktığı dili ana dili olarak kullanmayan kişiler tarafından nasıl algılandığı ve bu kişilerin zihinlerinde nasıl çözümlendiği, ne derece anlaşıldığı da araştırılması gereken konular arasındadır. Ancak genel itibariyle şu yargılara varmak mümkündür: Bir dilde ortaya çıkan çaprazlamalar, o dili yabancı dil olarak 
öğrenen konuşurlar için anlaşılamaz olabilir ve bu bakımdan iletişimde aksamaya yol açabilir. Diğer bir ifadeyle, çaprazlamalar sonucu ortaya çıkan yapılar, dile yabancı kişilerce fark edilmeyebilir. Dolayısıyla ortaya çoğu zaman anlamlı birimler çıkmayacağı için iletişimde aksamalar meydana gelebilir. Bu hususta diller arası sağlıklı çeviri de mümkün olmayabilir. Bilhassa yazıya yansımış çaprazlamalı yapıların doğru bir şekilde tercüme edilmesi, çevirmenin dikkati ve bilgisiyle mümkündür. Çaprazlamalar sonucunda zaman zaman tesadüfi olarak anlamlı yapılar ortaya çıksa da, bilhassa yabancı konuşurlar ve dinleyiciler için bu durum iletinin genel anlamını olumsuz yönde etkileyecek ve iletişimi sekteye uğratacaktır.

\subsection{Göçüşme ve Çaprazlama}

Çaprazlamalar, sesbilgisel unsurların konumlarının değişmesi noktasında göçüşme (metatez) ile benzerlikler gösterir. Göçüşmede konum değişimi (veya yer değiştirme) sözcük içerisindedir ve uzak/yakın olmak üzere iki türlü değişim mümkündür (Aksan 1995: 52; Ergin 2004: 52; Banguoğlu 2011: 70). Ancak çaprazlamalarda konum değişimi göçüşmeden farklı olarak bir sözcük içerisinde değil, birden fazla sözcük arasındadır. Bunun yanı sıra göçüşme, bir dilin varyantı için standartlaşmış biçimi yansıtıp konuşma hatası/dil sürçmesi olarak değerlendirilmezken, çaprazlamalar anlık olarak ortaya çıkıp doğal bir şekilde gelişir ve bir konuşma hatası/dil sürçmesi olarak algılanır. Örneğin bazı Anadolu ağızlarında bulgur yerine burgul veya toprak yerine torpak denilmesi, o ağzın konuşurları açısından bir yanlış olarak algılanmaz. Zira bu tür kullanımlar artık anlık olmaktan çıkmıştır ve o ağız için standart biçimi yansıtır. Dolayısıyla göçüşmeye uğramış biçimlerin farklı zaman ve mekânlarda farklı kişilerce kullanılması, bu kişiler tarafından birer "yanlış" veya "sürçme" olarak nitelendirilmemesi, dolayısıyla dikkat çekmemesi göçüşmeyi çaprazlamadan ayırır. Zira çaprazlamalar sonucu ortaya çıkan farklılaşmalar, bir "hata" olarak dinleyicilerin (ve konuşurların, yani 'hata'yı yapanların) dikkatini çeker. Bunun sonucunda konuşur, hatasını düzeltme yoluna gider veya dinleyici, konuşuru uyarabilir. Ancak standartlaşmış göçüşmelerde böyle bir durum söz konusu değildir. Ayrım, sadece farklı varyant konuşurları arasındadır. Buna karşın anlık göçüşmeler, dil sürçmesi görünümünde olabilir, yani dil veya varyant için standartlaşmamış göçüşmeler dil sürçmeleri olarak değerlendirilir.

Çaprazlamalar cümle düzeyini aşamazlar. Diğer bir ifadeyle, sadece bir cümle içerisinde ortaya çıkarlar. Bu da, konuşmanın zihinde cümle boyutunda planlandığına işaret etmektedir (Smyth vd. 2000: 195). Bunun aksine, göçüşmeler ise sözcük düzeyini aşamazlar. Göçüşme, sözcük düzeyini aştığı anda farklı bir mekanizma devreye girer ve bu durum göçüşme olmaktan çıkar. Diğer yandan standart biçim hâlini almış göçüşmeler dinleyici açısından anlaşılır durumdayken, bazı çaprazlamalar sonucu ortaya çıkan yapılar anlaşılmayabilir. Bu hususta, örneğin köprü > körpü göçüşmesi ilgili varyant konuşurları için standart ve anlaşılır biçimdir, ancak taş basması > baş tasması (TA: 380) veya gaz basa (< bas gaza) gibi çaprazlamalar, iletilmek istenen kavram veya mesajı değiştirecek, bozacak ve dolayısıyla iletinin genel anlamsal içeriğini olumsuz yönde etkileyip iletişimde aksamalara yol açacaktır.

\section{2. Çaprazlamaların Sebepleri}

Çaprazlamalar, dil dışı ve dil içi etkenlere bağlı olarak ortaya çıkabilir. Ancak dil içi etkenler ikincildir. Diğer bir ifadeyle, öncelikli etken dil dışıdır. Dil dışı etken sağlandıktan sonra dil içi etkenler çaprazlamayı şekillendirir. Dil dışı etkenler ise genellikle insan fizyolojisi ve psikolojisiyle ilgilidir. Bu hususta Potter, çaprazlamaların, beynin ön kısmında meydana gelen ve dil yetisini etkileyen bir kusurdan kaynaklanabileceğini belirtir (1980). Bu gibi patolojik vakalar haricindeyse açlık, sinirlilik, heyecan, duygusal yoğunluk, psikolojik gerginlik, 
kaygı, korku, başka bir şey düşünüyor olmak vb. durumlar çaprazlamaları ortaya çıkaran etkenler arasında sıralanabilir. Örneğin, kalabalık bir ortamda gürültüden rahatsız olan kimsenin sinirlilik hâliyle Sesin kesinizi! (< kesin sesinizi!) çaprazlamasını ortaya çıarması, buna bir örnektir. Ancak çaprazlamalar herhangi bir nedene bağlı olmadan, yani sıralanan şartlar sağlanmadığı zamanlarda da ortaya çıkabilir. Bu hususta, özellikle Türkçe için, disiplinler arası bir şekilde belirtilen şartlar sağlandığında veya bu şartlar sağlanmadan yapılacak deneysel ve gözlemsel çalışmalar, çaprazlamaların en çok hangi durumlarda ortaya çıktığı hakkında fikir verecektir. Öte yandan dil içi etkenler, çaprazlamayı ortaya çıkaran sesçe, işlevce, konumca veya anlamca benzerliktir. Bu bakımdan, örneğin Körün göz mü? (< Gözün kör mü?) gibi bir çaprazlamada, konum değiştiren /g/ ile /k/ ve /z/ ile /r/ seslerinin nitelik olarak en az bir yönüyle benzerlik taşıdıkları, aynı zamanda çevre seslerinin de (/ö/) aynı olduğu görülecektir.

Çaprazlamalar yazım esnasında da ortaya çıkabilir. Bu hususta, örneğin klavyede hızlı yazımdan kaynaklanan çaprazlamalara rastlanabilir. Ancak bu durum sonrasında kolayca fark edilebileceğinden, düzelti imkânı bulunmaktadır ve bu tür çaprazlamaların tespiti kolaydır. Yine de, bu durum, zihindeki düşüncelerin ve sözcüklerin yazıya geçirilmesi esnasında da konuşmayla benzer süreçlerin yaşandığına işaret etmesi bakımından önemlidir. Bunun yanı sıra, yukarıda belirtildiği gibi oyun, eğlence (muziplik), alay ve stilistik amaçlarla da çaprazlamalara başvurulabilir. Böylece, okuyucunun veya dinleyicinin dikkatinin çekilmesi sağlanabilir. Örneğin (1)'de görüleceği üzere, kişinin burnunda çıkan sivilcenin büyüklügüünü vurgulamak için, muziplik amaciyla çaprazlamaya başvurulmuştur:

(1) Sivilcende burun çıkmış birader.

(www.facebook.com/ANaKiinNTV/videos/1661052750818396, erişim tarihi: 07.04.2016)

Ayrıca edebî eserlerde de stilistik amaçlı çaprazlama örneklerine rastlanmaktadır. Bunlar ses düzeyinde olabileceği gibi (2a) sözcük düzeyinde de olabilir (2b).

(2) a. Çapalı Karşı (< Kapalı Çarşı)

b. Hiçölmüyor mu kanlı nigâr

bir ay girerken yüreğine geceleri rastıkları kaşlı hiç. (< kaşları rastıklı).

(Cöntürk 2006: 448-449)

\section{3. Çaprazlamaların Sınıflandırılması}

Çaprazlamalar, ses düzeyinde ortaya çıkanlar ve sözcük düzeyinde ortaya çıkanlar olmak üzere iki türlüdür. Bunların ilkinde çaprazlanan unsur ses veya seslerle sinırlıyken, ikincisinde sözcükler veya daha geniş anlamda biçimbirimler çaprazlamaya maruz kalır. Bu bakımdan, Türkçeden hareketle çaprazlama şeklindeki dil sürçmeleri, ortaya çıkışlarını ilgilendiren iki temel (sesbilgisel ve biçimbilgisel) süreç kapsamında ana hatlarıyla şu şekilde sınıflandırılıp tanımlanabilir:

\subsubsection{Ses düzeyinde çaprazlama}

Bu çaprazlama türünde, çaprazlanan unsurlar bir veya birden fazla ses olabileceği gibi hece boyutunda ses dizisi de olabilir. Ünlüler ünlüyle, ünsüzler ise ünsüzle çaprazlanır. Benzer veya ayn fonetik özellikleri taşıyan sesler arasında çaprazlama olabileceği gibi, tamamen farklı sesler arasında da çaprazlama ortaya çıkabilir. Bu da, sesbilgisel çaprazlamada seslerin fonetik açıdan aynılı̆̆ın veya benzerliğgin etkisiz olabileceğine işaret eder. Örneğin çok sık gerçekleştirilen bir 
çaprazlama olarak yanayan kara (< kanayan yara) ${ }^{4}$ kullanımında konum değiştiren /y/ ve /k/ ünsüzleri arasında akıcılık, patlayıcılık, art veya ön damakta meydana gelme gibi hususlar bakımından herhangi bir ortak nokta/paylaşılan nitelik bulunmaz. Ancak takip eden /a/ sesinin çaprazlamayı kuvvetlendirdiği belirtilebilir. Dolayısıyla çevre seslerin etkisinin ses düzeyindeki çaprazlamalarda önemli olduğu belirtilebilir.

Ses düzeyindeki çaprazlamalarda konum değiştiren sesler hacimce eşittir. Dolayısıyla bir sözcüğün bir sesi, karşılık sözcüğün yine bir sesiyle, söz gelimi üç sesi, karşılık sözcüğün yine üç sesiyle konum değiştirir. Aksi hâlde sesbilgisel çaprazlamanın esas ölçütü karşılanmamış olur. Bazı sesbilgisel çaprazlamalar ses dizilerinin konum değiştirmesiyle gerçekleşir ve bunlar ses/hece boyutunu da aşar: yumuklu sucurta (< sucuklu yumurta) gibi. Bu örnekte de görüleceği üzere, konum değiştiren sesler (/yum/ - /suc/) bir dizi hâlindedir ve sesletimsel olarak hece boyutunu da aşmaktadır. Yine de, ne kadar uzunlukta olursa olsun, konum değiştiren birimlerin eşit olması esastır. Ayrıca sadece sözcüklerin başında değil, sonunda da çaprazlamalar ortaya çıkabilir (3):

(3) kavuz karpun (< kavun karpuz)

(www.hocam.com/forum/89329/16/annelerin_gulduren_laflari/, erişim tarihi: 13.04.2016)

Çaprazlamada takip eden seslerin aynı veya benzer niteliklere sahip olması da, bu sürçmenin ortaya çıkmasını kolaylaştıran etkenlerdendir. Dolayısıyla çevre seslerin etkisinin çaprazlamada önemli olduğu savunulabilir. Örneğin bas gaza yerine gaz basa çaprazlamasında, konumu değiştirilen /b/ ve /g/ ünsüzlerinin her ikisinin de ardından /a/ ünlüsünün geldiği görülecektir. Belli seslerin yoğunluğu ve baskınlığı da ses düzeyinde çaprazlamaya sebep olabilir. Örneğin (4)'te, /r/ seslerinin baskınlığı, çevrelerindeki ses dizilerinin çaprazlanmasını ortaya çıkarmıştır (çaprazlananlar /fe/ > / k(1)/).

(4) Kirro Ferom tesisleri (< Ferro Krom tesisleri)

(www.internethaber.com/siyasetcilerin-en-unutulmaz-gaflari-foto-galerisi-1183122.htm?page =7, erişim tarihi: 12.04 .2016 )

Çaprazlamalarda, çaprazlanan unsurların ardından gelen ünlüler Türkçenin ses uyumuna uygunluk göstermeye devam eder. Örneğin (5)'te $/ \mathrm{s} />/ \mathrm{k} /$ çaprazlamasına rağmen, ilk sözcükteki ön sıradan ünlüler art sıradan ünlülere dönüşmüştür. Aynı işlem çaprazlanan karşılığa da uygulanmıştır.

(5) Kurudan ayrilanı sürt kapar.

(tr.instela.com/dil-surcmesi---1148113, erişim tarihi: 13.04.2016) ${ }^{5}$

Ses düzeyindeki çaprazlama, sözdizimi içerisinde konum olarak birbirine yakın sözcükler arasında veya aynı söz öbeği içerisinde ortaya çıkar. Dolayısıyla bu türden çaprazlamalar, daha çok birbirini takip eden sözcüklerle sinırlıdır. Bunda ise, çaprazlamaya konu sözcüklerin zihinde sıralanışı ve dizilişi ön plandadır. Ancak takip eden seslerin aynı olması durumunda, çaprazlamanın sesle veya heceyle mi, yoksa sözcük düzeyinde mi gerçekleştiği bazen belirsizdir. Örneğin sesin kesinizi örneğinde ilk sesler (/s/ ve /k/) çaprazlanmıştır, ancak sonraki

410 Aralı 2015 ve 11 Aralık 2015 tarihli Fox TV Ana Haber Bülteninde Fatih Portakal, iki gün üst üste yanayan kara çaprazlamasını gerçekleştirmiştir. Ayrıca genel ağdaki çeşitli sayfalarda da bu çaprazlamayla ilgili verilere ulaşmak mümkündür (örneğin bk. tr.instela.com/yanayan-kara--670875).

Bu örnekte, çaprazlanan unsurları/sür/ ve /kur/ ses dizileri olarak değerlendirmek de mümkündür. Zira konum değişmelerinin sadece /s/ ve /k/ sesleriyle sınırlı olduğu düşünüldüğünde, yeni yapının "Kürüden ayrılanı surt kapar." şeklinde biçimlendirilmesi gerekecektir. Oysa yeni yapı bundan uzaktır. Ancak öte yandan, /s/nin öndamaksıllaştırıcı etkisinden söz etmek de mümkündür. 
benzer ses ve heceler (/se/ ve /ke/), hatta sözcük kökleri de (ses ve kes-) arka planda çaprazlanıyor olabilir. Ancak biçim aynılığı dolayısıyla bunu belirlemenin imkânı yoktur. Bu bakımdan, ilgili hususta farklı yorumlamalar mümkündür. Dolayısıyla sesin kesinizi çaprazlamasında çaprazlanan unsurların sadece ilk seslerle, yani tek sesle sınırlı olduğunu savunmak kadar, sözcük köklerinin, hatta dört sesin (/sesi/ > /kesi/) çaprazlandığını belirtmek de mümkündür. Daha da ileri giderek, kesin yüklemi ile /sesin/ ses diziminin konum değiştirdiği de savunulabilir.

\subsubsection{Sözcük düzeyinde çaprazlama}

Bu çaprazlama türünde, konum değiştiren unsurlar sözcükler, yani anlamlı birimlerdir. $\mathrm{Bu}$ birimlerin çaprazlanması, dilbilgisel açıdan doğru (kurallı), ancak mantıkça yanlış (anlamsız) yapılar ortaya çıkarmaktadır. Örneğin Söz sükutsa gümüş altındır. (< Söz gümüşse sükut altındır.) gibi bir çaprazlama, dilbilgisel dizilim açısından doğru olmasına rağmen anlamca belirsizlik taşımaktadır. Yine de, uygun bağlamda bu çaprazlama, dinleyicinin de kalıp ifadeye ve bağlama hâkim olması durumunda iletinin taşıdığı mesajı aktarmada yeterli olacak ve herhangi bir olumsuzluğa yol açmayacaktır.

Sözlüksel çaprazlama, aynı sözcük sınıfından unsurlar arasındadır. Diğer bir ifadeyle, ad sınıfından sözcükler yine adla, eylem sınıfından sözcükler ise yine eylem sınıfından sözcüklerle çaprazlanabilir. Farklı sınıflardan sözlüksel unsurların çaprazlanması mümkün değildir. Örneğin (6)'da çaprazlanan unsurlar ad sınıfındandır:

(6) Cenab-ı Allah'ı sizlere emanet ediyorum.

(www.hurriyet.com.tr/allahi-sizlere-emanet-ediyorum-103283, erişim tarihi:

12.04.2016).

Ses düzeyinde çaprazlamalarda konum değiştirme birbirini takip eden sözcükler arasında ortaya çıarken, sözcük düzeyinde çaprazlamalarda birbirlerine konumca uzak unsurlar da çaprazlanabilir. Ancak sözlüksel olarak çaprazlanan unsurlar arasında genellikle anlamsalbağlamsal açıdan ilişkili olma söz konusudur. Bunlar ise zıt anlam, yakın anlam, eş anlam gibi anlam kategorileriyle ilgilidir. (7)'de görüleceği üzere, zıt anlamlı sözcükler çaprazlanmıştır:

(7) Biz bu bölgede barış değil, savaş istiyoruz.

(www.sabah.com.tr/galeri/turkiye/siyasetcilerin-unutulmaz-gaflari, erişim tarihi: 12.04.2016).

Atasözü ve deyim gibi kalıp ifadelerde sözcük boyutundaki çaprazlamalara sıkça rastlanılmaktadır. Ancak bunlardan hangisinin çaprazlama hangisinin bilgisizlik veya hatırlayamama sonucu ortaya çıktığını belirlemek güç olabilir. Zira Bakarsan dağ bakmazsan bă̆ olur (< Bakarsan bă̆ bakmazsan dağ olur) gibi bir çaprazlamanın dil sürçmesi sonucu mu yoksa atasözünü yanlış bilme/hatırlayamama dolayısıyla mı ortaya çıktığı belli değildir. Yine de, bağlamla ve mantıkla ilişkilendirildiğinde, böyle bir kullanım örneğinin dil sürçmesi sonucu ortaya çıkması daha olası görünmektedir.

Bazı çaprazlamalar, genişleme özelliğine sahip olabilir. Diğer bir ifadeyle, çaprazlanan unsurlardan biri, aynı cümlede birden fazla defa yer alabilir: Dikenlerim tüy tüy oldu. (< Tüylerim diken diken oldu.) gibi. Bu durum, bir kalıp ifadedeki sözcüklerin dahi zihinde konum değiştirmeye maruz kalabileceğine işaret etmektedir. Benzer olarak, özel adlarda da Dağllk Karabağ > Bă̆llk Karadă̆ örneğinde olduğu üzere çaprazlamalar meydana gelebilir. Görüleceği üzere, çaprazlamalarda sözcüklerin konum değiştirmesine rağmen eklerin ve diğer dilbilgisel 
unsurların yeri değişmez.

Bu türden çaprazlamalarda sadece sözcükler değil, sözcük öbekleri de çaprazlanabilir. (8)'de görüleceği üzere $i k i$ el ve kafa sözcükleri konum değiştirmiş ve bu unsurlara getirilen ekler değişmemiştir:

(8) Herkes iki elini kafasinın arasina alsin.

(www.vidivodo.com/osman-gokcek-herkes-iki-elini-kafasinin-arasina-alsin, erişim tarihi: 13.04.2016).

$\mathrm{Bu}$ örnekten de anlaşılacağı üzere, ses uyumu ve eklenme hususiyetleri yeni şekillenmeye göre devam etmektedir. Bu da, sözcüklerin konum değiştirmesine rağmen zihinde dilbilgisel düzenin devam ettiğine, ses uyumlarının ve çekimlerin korunduğuna, dolayısıyla, bir bakıma insan beyninin dili işleme gücüne işaret etmektedir.

\section{SONUÇ}

Dil sürçmeleri, konuşmanın farklı bir yönünü oluşturur ve çok farklı sebepler, uyaranlar dolayısıyla ortaya çıkar. Dil sürçmelerinin ortaya çıkışını ve öncesini her şeyden önce psikolojik veya nörolojik/patolojik bir olgu olarak değerlendirmek gerekecektir. Ancak ortaya çıkışlarından sonraki aşamaların incelenmesi ve sınıflandırılması dilbilimsel yaklaşımlarla mümkündür. Bu çalışmada da, biçimlenmiş ve tamamlanmış çaprazlama türündeki dil sürçmeleri çeşitli yönleriyle genel bir incelemeye tabi tutulmuştur.

Freud'un savunduğu, "Dil sürçmeleri bilinçaltının dışavurumudur." şeklindeki varsayım göz önüne alındığında, çaprazlamaların bilinçaltı düşüncelerle ilişkilendirilmesi güç görünmektedir. Zira çoğu durumda, bu dil sürçmesi türünde, bilinçaltındaki bir durumun dişa vurulması söz konusu olamaz. En basit hâliyle, iki sözcüğün ilk seslerinin yer değiştirmesini bilinçaltıyla ilişkilendirmek mantıklı görünmemektedir. Ancak çaprazlama dâhil olmak üzere tüm dil sürçmeleri, dilin işleyiş mekanizmasını ortaya çıkarma açısından önemlidir. Bu noktada bilişseldilbilim, psikodilbilim gibi dilbilimin alt çalışma alanları ve ilgili disiplinler, sürçmeler üzerinden dil yetisiyle ilgili önemli yargılara varabilir.

$\mathrm{Bu}$ makaleyle, dil sürçmelerinin bir alt türü olan çaprazlamaya Türkçe açısından yaklaşılmış ve Türkçeden örneklerle bu konudaki evrensel literatüre katkıda bulunulmaya çalışılmıştır. Ancak, Türkçedeki bu ve benzeri dil sürçmeleri üzerine yapılacak daha kapsamlı ve deneysel çalışmalara ihtiyaç bulunmaktadır. Ayrıca çeşitli ortamlardan yapılacak gözleme dayalı çalışmalar sonucunda geniş bir dil sürçmesi veri tabanı/derlemi hazırlanabilir. Böylece, Türkçedeki dil sürçmeleri daha kapsayıcı olarak sınıflandırılabilir ve genel olarak Türkçenin işleyişi, Türkçe cümle ve öbek yapılarının beyinde nasıl üretildiği ve insan zihninde nasıl planlandığı gibi konulardaki çalışmalara çeşitli açılardan katkı sağlanabilir. Tüm bunlarla, Türkçenin bu açıdan psikodilbilimsel olarak incelenmesi noktasında çeşitli kazanımlar elde edilmiş olacaktır. 


\section{KAYNAKÇA}

AKSAN, Doğan (1995), Her Yönüyle Dil, Ana Çizgileriyle Dilbilim, Ankara: Türk Dil Kurumu Yayınları.

BAARS, Bernard J. (1992), Experimental Slips and Human Error: Exploring the Architecture of Volition, New York: Springer.

BANGUOĞLU, Tahsin (2011), Türkçenin Grameri, Ankara: Türk Dil Kurumu Yayınları.

CARROLL, David W. (2008), Psychology of Language, Belmont: Thomson West.

CÖNTÜRK, Hüseyin (2006), Çă̆ının Eleştirisi - Birinci Kitap (haz. Ege Berensel), İstanbul: Yapı Kredi Yayınları.

CUTLER, Anne (1982), Slips of the tongue, The Hague: Mouton.

DELL, Gary S. (1986), A spreading-activation theory of retrieval in sentence production, Psychological Review 93, 283-321.

DTS=Komisyon (1949), Dilbilim Terimleri Sözlüğ̈̈, Ankara: Türk Dil Kurumu Yayınları.

ERGIN, Muharrem (2004), Türk Dil Bilgisi, İstanbul: Bayrak Basım/Yayın/Tanıtım.

FREUD, Sigmund (1995), The Basic Writings of Sigmund Freud (çev. A. A. Brill), New York: Random House.

FROMKIN, V. A. (ed.) (1973), Speech Errors as Linguistic Evidence, The Hague: Mouton

FROMKIN, Victoria A. (ed.) (1980), Errors in Linguistic Performance: Slips of the Tongue, Ear, Pen and Hand, New York: Academic Press.

GOLDSTEIN, Bruce E. (2008), Cognitive Psychology: Connecting Mind, Research, and Everyday Experience, Belmont: Thomson Wadsworth.

HOFSTADTER, R. Douglas (1995), Speechstuff and Thoughtstuff: Musings on the Resonances Created by Words and Phrases via the Subliminal Perception of their Buried Parts, Of Thoughts and Words: The Relation between Language and Mind, Proceedings of the Nobel Symposium 92. (ed. Sture Allén). London/New Jersey: World Scientific Publishing, 217-267.

HORBERRY, Roger (2010), Sounds Good on Paper: How to Bring Business Language to Life, London: A \& C Black.

KARAAĞAÇ, Günay (2013), Dil Bilimi Terimleri Sözlüğ̈̈, Ankara: Türk Dil Kurumu Yayınları.

KEMMERER, David (2015), Cognitive Neuroscience of Language, New York and London: Psychology Press.

POTTER, John M. (1980), What was the matter with Dr. Spooner?, Errors in Linguistic Performance: Slips of the Tongue, Ear, Pen and Hand (ed. V. A. Fromkin), New York: Academic Press, 13-34.

SMYTH, Mary M., Alan F. Collins, Peter E. Morris, Philip Levy (2000), Cognition in Action, Hove: Psychology Press.

SOFU, Hülya (2001), Dil Sürçmeleri, XV. Dilbilim Kurultayı Bildiriler Kitabı (ed. Ömer Demircan ve Aybars Erözden), İstanbul: Yıldız Teknik Üniversitesi Basım-Yayın Merkezi.

TA=Komisyon (1963), Türk Ansiklopedisi, C. XI, Ankara: Milli Eğitim Basımevi.

USTA, Çiğdem (2005), Mizah Dilinin Gizemi, Ankara: Akçă̆ Yayınları.

WARREN, Paul (2013), Introducing Psycholinguistics, Cambridge: Cambridge University Press. 